\title{
Effect of Moxibustion Therapy on Intensity of Primary Dysmenorrhea in Adolescents Girl at Cimahi Negeri 2 Junior High School
}

\section{Achmad Setya Roswendi}

Sekolah Tinggi llmu Kesehatan Jenderal Achmad Yani, Cimahi, Indonesia

ORCID:

Achmad Setya Roswendi: https://orcid.org/0000-0002-7922-858X

\section{Abstract}

Based on the data from the World Health Organisation (WHO), primary dysmenorrhea is prevalent among 55-75\% adolescent girls and women of reproductive age. Threequarters of these women experienced mild-moderate dysmenorrhea. One of the non-pharmacological treatments for dysmenorrhea is moxibustion therapy. The heat from moxa is able to stimulate sensory nerve cells around the acupoints and can affect the endocrine system to release endorphins and also inhibit pain impulses in spinal

Corresponding Author: Achmad Setya Roswendi murtiningsih.unjani2019@ gmail.com

Published: 15 March 2021

Publishing services provided by Knowledge E

(c) Achmad Setya Roswendi. This article is distributed under the terms of the Creative Commons Attribution License, which permits unrestricted use and redistribution provided that the original author and source are credited.

Selection and Peer-review under the responsibility of the IVCN Conference Committee. cord. This research design was quasi-experiment with non-equivalent control group design, using non-probability with purposive sampling technique, which obtained 54 samples consisting of 27 in each intervention and control groups. Mean was used in univariate analysis and t-dependent also t-independent tests was used in bivariate analysis. This research occured at Cimahi Negeri 2 Junior High School. In the intervention group the therapy was given in one-time, 1 inch above the 9 acupoints within 15 minutes long, while in the control group no intervention was given. The results of the study proved the differences in the mean pain scale values of primary dysmenorrhea in the intervention group and the control group ( $p$-value $=$ 0.000 ) so that there is an effect of moxibustion therapy on the intensity of primary dysmenorrhea in adolescents. Moxibustion therapy can be recommended to be applied as a non-pharmacological action to treat dysmenorrhea and can be done independently.

Keywords: Acupoints, Moxibustion Therapy, Primary Dysmenorrhea

\section{Introduction}

The incidence of primary dysmenorrhoea in Indonesia itself is quite a lot, namely as much as 55-75\% among women of childbearing age based on WHO data (Putri, 2017). The incidence of primary dysmenorrhea in West Java is quite high, the results of the study found an incidence of $54.9 \%$ consisting of $24.5 \%$ experienced mild dysmenorrhoea, $21.28 \%$ experienced moderate dysmenorrhoea and $9.36 \%$ experienced severe dysmenorrhoea (Savitri, 2015). The conclusion from the above data is the incidence of 
dysmenorrhoea in Indonesia, especially West Java, more than half percent have primary dysmenorrhoea with different levels of pain, namely mild, moderate and severe pain.

Dysmenorrhoea can affect a woman's physical and psychological condition. Physical conditions such as pain in the lower abdomen, waist, and even back will cause discomfort in daily physical activity. These complaints are related to repeated absence from school, limited social life, academic performance, and sports activities. In psychological conditions such as being easily offended, bad moods, irritability, weakness, and anxiety will affect the ability of a teenager. This complaint shows a bad influence when experiencing dysmenorrhoea with work productivity and women's behavior (Puji, 2011).

The problem of adolescents who experience dysmenorrhoea can be overcome by pharmacological or non-pharmacological therapy. Nonpharmacological therapies include adequate rest, consuming warm drinks, relaxation or yoga, doing physical activities such as sports, cycling, aerobics, bathing with warm water and warm compresses on the painful part (Komalasari, 2012). All of these actions have been investigated before but only reduce the pain until the pain has been relieved, and for the application of warm compresses not in accordance with the point that can reduce pain. In addition, there are other non-pharmacological therapies including Traditional Chinese Medicine (TCM) treatments, namely acupuncture, acupressure, tuina, acupuncture auricular, and moxibustion therapy (Mingxiao, et al., 2017).

TCM is divided into 2 namely therapy that uses needles and therapies that do not use needles. TCM therapy that uses needles such as acupuncture and acupuncture auricular requires skill and certified training. TCM therapy that does not use needles is acupressure, tuina, and moxibustion.

Acupressure and tuina therapy require skills, and certified training, while moxibustion therapy is an easy therapy for adolescents to do independently without a doctor's prescription, only given heat stimulation at the point of acupoints, without using needles, is usually the therapy of choice to eliminate all types of pain and it can be said that moxibustion therapy without side effects needs to be feared and improvements occur for a long time (Koosnadi, 2017). According to the results of research Myeong Soo Lee (2010) moxibustion therapy can reduce cancer pain and shingles due to an increase in $\beta$-endorphin levels in the body.

Moxibustion is one of the non-pharmacological therapies using moxa warming. Moksa is a cylindrical or cone-shaped device made from dried plants, namely Hia (Artemisia vulgaris) leaves, to warm the acupuncture / acupoint points. This plant is shown to increase blood circulation to the pelvic area, uterus, stimulate menstruation and overcome cramps during menstruation / dysmenorrhoea (Kiswojo, 2013). Provision of heat 
stimulation at the acupuncture point with moxibustion techniques can overcome pain sensations through increased endorphin, a hormone that is able to bring a relaxed feeling to the body naturally, blocking pain receptors to the brain (Aprilia, 2010). Mingxiao Yang et al (2017) used moxibustion therapy with 3 acupoints, namely Guanyuan (CV4), Shenque (CV8), and Sanyinjiao (SP6) to 133 female students in Chengdu City (69 women in the moxibustion group and 64 women in the ibuprofen group) shows that both interventions (conventional medicine and moxibustion therapy) can reduce menstrual pain. Both interventions show the desired benefits of managing menstrual pain. However, previous studies only showed effectiveness, not efficacy, moxibustion for menstrual pain. The difference of previous research with this research is to use 9 acupoints namely Guanyuan (CV4), Shenque (CV8), Sanyinjiao (SP6), Tianshu (ST25),Wailing (ST26), Shuidao (ST28), Qichong (ST30), Neiting (ST44), and Yinlingquan (SP9) to respondents with the characteristics of early adolescents aged 11-14 years, by administering moxibustion therapy for 15 minutes. According to Mingxiao Yang et al (2017) applying some moxibustion stimulation to several acupoints in the lower abdomen that are located anatomically above the uterus. Heat stimulation can increase blood flow in blood vessels near the uterus which causes secretion of prostaglandins, bradykinin, histamine in intravascular to increase blood flow also increases tissue oxygenation. According to Koosnadi (2017) sufferers who receive moxibustion therapy experience a decrease in pain (cramping pain), and an improvement in extra genital symptoms, such as nausea, headaches, back pain, premenstrual symptoms caused by fluid retention, and breast tension. This complaint can improve in one treatment, so this study hopes to show the efficacy of moxibustion therapy to overcome menstrual pain.

Based on data from the city of Cimahi, it is explained that SMP Negeri 2 Cimahi has the highest number of female students and the highest incidence of dysmenorrhea so that researchers are interested in conducting research at Cimahi 2 Public High School. "The purpose of this study was to determine the effect of moxibustion therapy on the intensity of primary dysmenorrhoea in adolescent girls in Cimahi State Junior High School 2.

\section{Methods}

The method in this study uses a quasi-experimental nonequivalent control group design. The hypothesis in this study is an alternative hypothesis $(\mathrm{Ha})$ that is the influence of moxibustion therapy on the intensity of primary dysmenorrhea pain in young women in Cimahi State Junior High School 2. The independent variable of this study is moxibustion 
therapy and the dependent variable of this study is the intensity of primary dysmenorrhoea. Measuring instruments used in measuring pain scale using NRS (Numeric Rating Scale). Scale 0: No pain, Scale 1-3: Mild pain, Scale 4-6: Moderate pain, Scale 7-9: Severe pain, Scale 10: Very severe pain. The populations in this study were students of Cimahi VII and VIII SMP Negeri 2 who experienced primary dysmenorrhea as many as 275 people.

The sampling technique used purposive sampling. The inclusion criteria in this study were students who experienced primary dysmenorrhoea on the first 24 hours, girls were not using analgesic drugs, herbs, warm water compresses, and gymnastics when dysmenorrhea was felt before the intervention, willing to intervene moxibustion therapy. Exclusion criteria in this study were students who experience uncontrolled dysmenorrhoea pain such as vomiting and fainting.

a. From the calculation results obtained 60 samples consisting of 30 samples of the intervention group and 30 respondents as a control group. In the intervention group, respondents performed moxibustion when the respondent experienced pain, before respondent intervention was measured first (pre-test). Used the NRS pain scale questionnaire to measure the pain scale before the intervention. When intervening in a relaxation position such as supine or semi fowler and say Bismillah before moxibustion therapy is carried out. Then the researchers conducted moxibustion therapy on the target (akupoint) 1 inch $(2.5 \mathrm{~cm}$ ) for 15 minutes at 9 points namely Guanyuan (CV4), Shenque (CV8), Sanyinjiao (SP6), Tianshu (ST25), Wailing (ST26), Shuidao (ST28), Qichong (ST30), Neiting (ST44), and Yinlingquan (SP9). Moxibustion therapy is carried out at each point for 65 seconds. After the intervention was carried out for 15 minutes, the researcher gave a pain scale questionnaire to be filled in by the respondent (post-test). Then the documentation was carried out. The validity of the instruments in this study used the NRS questionnaire from Potter \& Perry in 2009 and the moksa which had been tested by POM Agency no. NA18170701151, so it did not need to be tested for validity. This is by the opinion of Riyanto (2011) that the validity test is only used for instruments that do not yet have a standard. In this study the questionnaire and moksa used were standard so there was no need for reliability testing. Peneliti mengajukan surat pemohonan izin pengambilan data kepala Sekolah SMP Negeri 2 Cimahi, meminta bantuan kepada humas dari sekolah untuk mengumpulkan siswi kelas VII dan VIII, Peneliti memperkenalkan diri, menjelaskan tujuan dan waktu tindakan, melakukan proses penyeleksian responden yang sering mengalami dismenorhea, membagikan kuesioner dan inform consent pada responden yang mengalami dismenorhhe, melakukan pencatatan nama, kelas dan nomer telephone responden untuk mempermudah peneliti menghubungi 
responden. Membagi 2 kelompok menjadi kelompok control dan kelompok intervensi masing masing 30 responden, Pada kelompok control peneliti mendatangi responden di kelas untuk memberikan kuesioner skala nyeri (pre-test) dan setelah 15 menit responden diberikan kuesioner skala nyeri (post-test). Selanjutnya kelompok intervensi dilakukan di ruang khusus (UKS) selama 15 menit kepada 2-6 orang setiap harinya dengan didampingi 2 orang asisten yang membantu pemberian intervensi dimana terlebih dahulu telah dilakukan persamaan persepsi. Sebelum melakukan penelitian, responden kelompok intervensi yang mengalami dismenorea primer akan dilakukan pre-test tentang skala nyeri nya, dengan posisi relaksasi seperti supine atau semi fowler. Kemudian peneliti melakukan terapi moksibusi di atas begian sasaran (akupoint) 1 inci $(2,5 \mathrm{~cm}$ ) selama 15 menit pada 9 titik yaitu Guanyuan (CV4), Shenque (CV8), Sanyinjiao (SP6), Tianshu (ST25), Wailing (ST26), Shuidao (ST28), Qichong (ST30), Neiting (ST44), dan Yinlingquan (SP9). Terapi moksibusi dilakukan pada setiap titik selama 65 detik. Setelah intervensi dilakukan selama 15 menit, peneliti akan memberikan kuesioner skala nyeri untuk post- test, kuesioner yang telah diisi dilakukan editing, entri data, procesing dan cleaning, dan analisis menggunakan komputer.

Univariate analysis was used to describe the average value of primary dysmenorrhoea intensity before and after moxibustion therapy in the treatment group as well as the average value of primary dysmenorrhoea intensity in the control group. Researchers observed the intensity of primary dysmenorrhoea before and after moxibustion therapy in the intervention group.

Normality test of data distribution uses Kolmogorov-Smimov value because the total sample is more than 50 . In this study the intervention group got a significant value with a pre-test value of 0.075 and post-test average value of 0.085 , it can be concluded that the data are normally distributed, because average $>0.05$. While in the control group, the pretest average value of 0.051 and the posttest average value of 0.135 , it can be concluded that the data are normally distributed, because the average is $>0.05$.

Based on the results of normal data distribution, the univariate results use averages and bivariate analysis uses the paired t-test parametric test. Significance Test uses $p$ value. In carrying out this research the researcher pays attention to research ethics namely the right to participate or not be a respondent (right to self-determination), the respondent is not forced by the researcher or any party to know the research. Respondents follow the research on the basis of voluntary or the wishes of the respondents themselves and there has been informed consent given to parents. Respecting privacy and confidentiality, by not including the name of the respondent's identity and there are no therapists other than women, the researcher only writes the code on the 
data collection sheet or the results of the study with the initials of the name. Justice and inclusiveness (respect for justice inclusiveness), namely by providing a comfortable place that is clean and quiet. Taking into account the benefits and losses incurred (balancing harms and benefits), moxibustion is an action without causing injury, easily implemented is expected to reduce the incidence of pain in respondents.

\section{Result}

The location of this research was carried out at SMP Negeri 2 Cimahi and the student house. When the research was carried out into 3 stages, namely: the stage of preparing the research proposal in January-February 2019, the stage of conducting the research in 22 April - 17 May 2019, the last stage of the research report in July 2019.

Univariate results of the intervention group showed that the mean value of the pretest primary dysmenorrhoea pain scale in the intervention group was 4.33 (moderate pain scale) and the mean value of the postmen tain dysmenorrhoea pain scale in the intervention group was 1.89 (scale mild pain) there is a decrease in the average value of pain before and after the intervention of 2.444 .

The results of the control group univariate study showed that the mean value of the pre-test primary dysmenorrhoea pain scale in the control group was 4.07 (moderate pain scale) and the mean value of the postmen- tain dysmenorrhea pain scale in the control group was 4.15 (scale moderate pain) there is an increase in the average value before and after by 0.074 . The results of the Bivariate study showed that there was a difference in the average value of the primary dysmenorrhoea pain scale between the intervention group and the control group of 2.26. Statistical results with independent t-test obtained $p$ value $<\alpha(\alpha=0.05)$, it can be concluded that Ha can be accepted so that it can be interpreted that there is an influence of moxibustion therapy on primary dysmenorrhoea intensity in young women in SMP Negeri 2 Cimahi.

The discussion in this study is a decrease in the intensity of dysmenorrhoea in the intervention group due to the presence of warm stimulation from moxa transmitted by sensory nerve cells to the spinal cord and forwarded to brain stem cells. Pain originating from the uterus will be inhibited in the spinal cord by the ankafalin hormone released by brain stem cells. Then brain stem cells also stimulate the hypothalamus to produce physiological analgesics, $\beta$-endorphine (Kiswojo, 2013). In addition, the effectiveness of moxibustion also comes from chemical stimulation, which is from the treatment part in the leaves of Artemisia vulgaris. Thus, heat stimulation of moxibustion can activate nerve responses and induce vascular changes. 
Based on the results of earlier studies by Lee (2010) on Moxibustion for Treating Pain: A Systematic Review concluded that moxibustion therapy is useful in stimulating sensory nerve cells to affect the endocrine system releasing a number of endorphine. Where from the observations of the study there was a significant pain reduction for moxibustion in osteoarthritis and in herpes zoster pain compared with drug therapy.

Similar research results were also conducted by Yati (2019) about the physiological effects of the influence of acupressure and moxibustion techniques on decreasing the level of dysmenorrhoea pain in SMA Negeri 2 Sungai Penuh City. It can be seen the average scores before 4.80 and after 1.64 . It can be concluded that there is a significant decrease between the pain scale before and after the intervention. Based on this research, it can be concluded that acupressure and moxibustion techniques are effective for reducing dysmenorrhoea pain, but this technique has not concluded that moxibustion is the main ingredient in reducing pain because acupressure and moxibustion techniques have different properties.

Warm stimulation of the acupoint can be used as a diagnostic or therapeutic point that is directly related to the destination organ through its meridian trajectory. There are 18 acupoints to overcome dysmenorrhoea (Koosnadi, 2017). But in this study researchers used 9 acupoints namely Guanyuan (CV4), Shenque (CV8), Sanyinjiao (SP6), Tianshu (ST25), Wailing (ST26), Shuidao (ST28), Qichong (ST30), Neiting (ST44), and Yinlingquan (SP9), where the number of acupoints is located in the lower abdomen or anatomically above the uterus. Mingxiao Yang et al (2017) research results using moxibustion therapy with 3 acupoints, namely Guanyuan (CV4), Shenque (CV8), and Sanyinjiao (SP6). Of the 3 acupoints, two of the acupoints above the uterus show that performing moxibustion therapy at the place according to the acupoint and meridian points will cause treatment reactions, improvement and prevention of disease.

The provision of interventions in the form of moxibustion therapy in adolescents in SMP Negeri 2 Cimahi can be one form of intervention to overcome the problem of dysmenorrhoea. Scientifically / scientifically the use of research methodologies giving moxibustion therapy interventions has the effect of decreasing the intensity of primary dysmenorrhoea. Moxa burning according to the point and meridians can increase blood flow in blood vessels near the uterus and prostaglandin, bradykinin, histamine in the intravascular secretion to increase blood flow and increase tissue oxygenation.

This is supported by previous research conducted by Cui, et al. (2011) regarding the Effect of Acupoint Sanyinjiao (SP6) Moxibustion on the First Stage of Labor and Uterine Contraction Pain in Primipara revealed that there was a significant reduction in pain in the intervention group compared to the control group seen from the $p$ value of 0.001 . 
In this study, researchers used Sanyinjiao (SP6) acupoints to overcome uterine muscle tension. Performing moxibustion therapy at the appropriate point and meridian acupoint can have a major influence on overcoming the uterine muscle. The significant decrease in pain can be seen from the mean value in the intervention group of 2.25 while the mean value in the control group was 3.87. This shows a significant comparison of the average pain scale of 1.62 between the intervention group and the control group.

In another study also conducted by Mingxiao, et al. (2017) found that there was a decrease in the pain scale in the intervention group more significantly compared to the control group with a $p$ value of 0.01 . The decrease occurred because of moxibustion therapy with 3 acupoints namely Guanyuan (CV4), Shenque (CV8), and Sanyinjiao (SP6).

The three acupoints are located in the symphysis pubis and inner legs. This shows that the conduct of moxibustion therapy at the acupoints and meridians that pass through the destination organ will cause a treatment reaction, improvement and prevention right on the target disease. This is in line with research conducted by researchers in young women aged 12-13 years at SMP Negeri 2 Cimahi where in the intervention group there was a change in pain scale reduction compared to the control group. Warm stimulation of the acupoint can be used as a diagnostic or therapeutic point that is directly related to the destination organ through its meridian trajectory. There are 18 acupoints to overcome dysmenorrhoea (Koosnadi, 2017).

But in this study researchers used 9 acupoints namely Guanyuan (CV4), Shenque (CV8), Sanyinjiao (SP6), Tianshu (ST25), Wailing (ST26), Shuidao (ST28), Qichong (ST30), Neiting (ST44), and Yinlingquan (SP9), where the number of acupoints is located in the lower abdomen or anatomically above the uterus. This research is by the theory of Kiswojo (2013) moxibustion mechanism working locally, spinally and centrally. Stimulation of warm impulses from moksa which is transmitted by sensory nerve cells to the spinal cord and passed on to brain stem cells. Brain stem cells release ankafalin which will inhibit the delivery of pain impulses in the spinal cord, than brain stem cells also stimulate the hypothalamus to produce physiological analgesics, beta-endorphine.

This is also supported by research Dwita (2017) moxibustion therapy proven to increase beta endorphine hormone which inhibits impulse pain in the brain stem cell nerves. Warm power can break the energy crisis in the warmth place so that relaxation occurs, blood circulation and repair damaged tissue.

From the statements of all the theories above and the results of the analysis of research data in the intervention group and the control group, it was concluded that moxibustion therapy was effective in reducing the intensity of primary dysmenorrhoea in adolescent girls in SMP Negeri 2 Cimahi, this was evidenced by the intervention group 
given moxibustion therapy with a duration of 15 minutes at 9 acupoints scored lower than the pain intensity in the control group that was not given treatment in dealing with dysmenorrhoea. The decrease occurred because of the stimulation of warm impulses from moxa at 9 acupoints which are transmitted by sensory nerve cells to the spinal cord and passed on to brain stem cells. Brain stem cells will inhibit the delivery of pain impulses in the spinal cord and stimulate the hypothalamus to produce beta-endorphins in the blood.

In the results of research in the control group, which did not do moxibustion therapy has an increase in the value of the average intensity of primary dysmenorrhoea by a difference of 0.074 . Where from the 27 respondents found 15 respondents experienced pain intensity did not change before and after treatment, 9 respondents experienced pain intensity increased to moderate / severe pain and 3 respondents experienced pain intensity decreased below one number.

This is by the theory of Prawiroharjo (2018) which says that the cause of an increase in primary dysmenorrhoea occurs due to several factors namely psychiatric factors, constitution, obstruction, endocrine and allergies. But in general, primary dysmenorrhea occurs due to two factors, namely endocrine and psychiatric. Endocrine factors because increased uterine contractions. Prostaglandin F2 secreted by endometrial cells will stimulate the myometrium to contract which results in decreased oxygen supply to the uterus so that the uterine cell ischemic. Primary dysmenorrhoea generally arises from the first menstruation and will heal itself over time, precisely after the stability of the hormone. Meanwhile, according to Icesma (2013), psychiatric factors, namely stress and psychological stress, have a large role in causing the increase in primary dysmenorrhoea. Pain that starts at the onset (first menstruation) generally gets worse when stressed. Stress can interfere with the workings of the endocrine system, so that it can cause irregular periods and pain during menstruation or dysmenorrhoea.

The intensity of primary dysmenorrhoea was reduced in 3 respondents in the control group, due to distraction with music subjects so that respondents were happy and did not feel stressed, which could interfere with the work of the endocrine system. This is proven by Sari, Nurdin, \& Defrin's (2015) research stating that from the chi-square test results found that $82 \%$ of respondents experienced severe primary dysmenorrhoea with severe stress levels while $18 \%$ of respondents experienced mild primary dysmenorrhoea without stress.

At the time of the study, respondents in the control group were not given treatment, where respondents only did school learning activities. Based on the results of the statistical tests above, the theories and several research results prove that the absence 
of intervention in the control group of respondents experienced an increase in pain due to increased uterine contractions and stress.

The conclusion in this study is that there is a difference between the intervention group and the control group after moxibustion therapy intervention ( $p$ value $=0,000$ ).

\section{References}

[1] Cui, J., et al. (2011, June). Effect of Acupoint Sanyinjiao (SP6) Moxibustion on the First Stage of Labor and Uterine Contractive Pain in Primiparae. Chinese Journal of Integrative Medicine, issue 17, pp. 464-466. Retrieved from https://link.springer.com/ article/10.1007/s11655-011-0631-4\#citeas.

[2] Dahlan, M. S. (2016). Besar Sample Dalam Penelitian Kedokteran Dan Kesehatan. Jakarta: Salemba Mediaka.

[3] Dwita, O. and Sabrina, F. (2017). Efektivitas Moksibusi Untuk Rehabilitas Stroke. Medical Journal Of Lampung University. Issue 6, p. 8.

[4] Icesma, S. (2013). Kehamilan, Persalinan. Dan Nifas. Yogyakarta: Nuha Medika.

[5] Kiswojo. (2013). Akupunktur Medik. Jakarta.

[6] Komalasari. (2012). Kesehatan Reproduksi Untuk Mahasiswa Kebidanan dan Keperawatan. Jakarta: Salemba Medika.

[7] Koosnadi, S. (2017). Akupunktur Dasar. Surabaya: Airlangga University Press.

[8] Lee, M. S. (2010). Moxibustion for Treating Pain: A Systemic Review. The American Journal of Chinese Medicine 38(5):829-38. DOI: 10.1142/S0192415X10008275

[9] LeMone, P., et al. (2017). Buku Ajar Keperawatan Medikal Bedah. Jakarta: EGC.

[10] Li, Liu, H. (2007). Post Operatif Pain Intensity Assessment: A Comparison of Four Scale in Chinese Adult. Retrieved from http://www.ncbi.nlm.nih.gov/.

[11] Mingxiao, Y., et al. (2017). Moxibustion for Pain Relief in Patients with Primary Dysmenorrhea: A Randomized Controlled Trial. PLoS ONE, vol. 12, issue 2, p. 0170952.

[12] Muhamad, J. (2012). Teori Pengukuran Nyeri Dan Nyeri Persalinan. Yogyakarta: Nuha Medika.

[13] Notoatmodjo, S. (2015). Metodologi Penelitian Kesehatan. Yogyakarta: Rineka Cipta.

[14] Nursalam. (2014). Manajemen Keperawatan Aplikasi dalam Praktek Keperawatan Profesional ( ${ }^{\text {th }}$ ed.). Jakarta: Salemba Medika.

[15] Potter. P. (2009). Punda Mental Keperawatan (7 $7^{\text {th }}$ ed.). Jakarta: Salemba medika.

[16] Prawirohardjo, S. (2018). Ilmu Kebidanan. Jakarta: PT. Bina Pustaka. 
[17] Price, S. A. and WIlson, L. M. (2012). Patofisiologi: Konsep Klinis Proses-Proses Penyakit. Jakarta: EGC.

[18] Properawati. M. (2009). Menstruasi Pertama Penuh Makna. Yogyakarta: Nuha Medika.

[19] Puji. (2011). Efektivitas Senam Dismenorea Dalam Mengurangi Dismenorea Pada Remaja Putri Di SMUN 5 Semarang. Retrieved from http://eprints.undip.ac.id.

[20] Riyanto, A. (2011). Pengolahan dan Analisis Data Kesehatan. Yogyakarta: Nuha Medika.

[21] Riyanto, A. (2011). Statistik Interensial Untuk Analisis Dan Kesehatan. Yogyakarta: Nuha Medika.

[22] Saputra. S. (2009). Akupuntur Untuk Nyeri. Jakarta: CV Sagung Sero.

[23] Sari, D., Nurdin, A. E. and Defrin. (2015). Hubungan Stres dengan Kejadian Dismenore Primer pada Mahasiswi Pendidikan Dokter Fakultas Kedokteran Universitas Andalas. Jurnal Kesehatan Andalas, vol. 4, issue 2, pp. 567 - 570.

[24] Sastroasmoro, S. and Sofyan, I. (2011). Dasar Dasar Metodologi Penelitian Klinis. Jakarta: Sagung Seto.

[25] Savitri, R. (2015). Gambaran Sekala Nyeri Haid Pada Usia Remaja. Jurnal Keperawatan Aisyah. Vol 2 No 2. Page 25 - 29

[26] Yati, S. (2019, April 5). Akupresur dan Moksibusi Terhadap Penurunan Tingkat Nyeri Pada Siswi Kelas X Yang Mengalami Dismenore Primer Di SMA Negeri 2 Kota Sungai Penuh Tahun 2015. Jurnal Penelitian dan Kajian IImiah In Menara IImu, XIII, pp. 122 128. 